\title{
Key Plant, Key Pests: Baldcypress (Taxodium distichum) ${ }^{1}$
}

Juanita Popenoe, Caroline R. Warwick, and Roger Kjelgren²

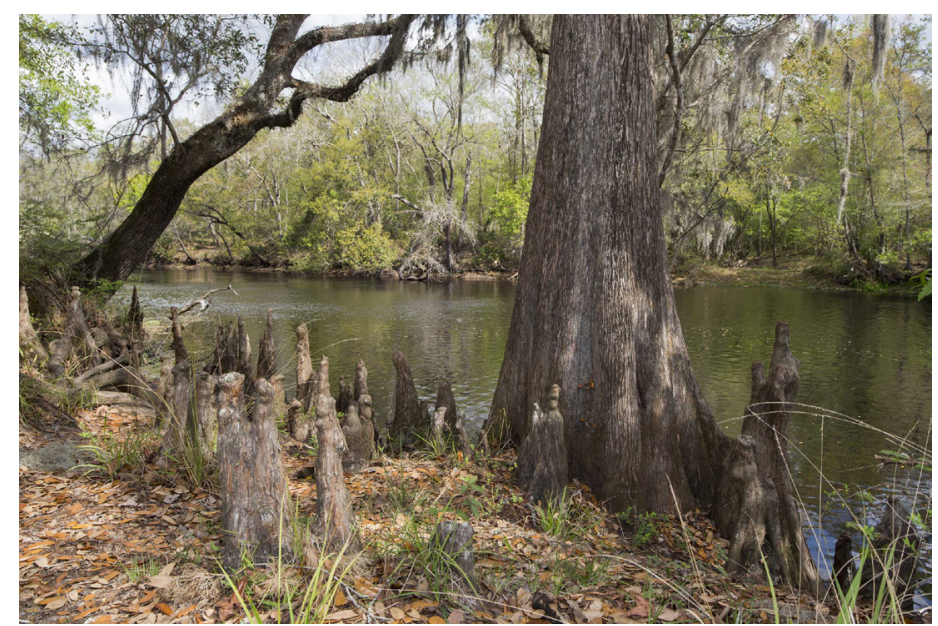

Figure 1. Baldcypress trees can often be seen on lake and river shores throughout Florida.

Credits: Tyler Jones, UF/IFAS

\section{Key Plant: Baldcypress (Taxodium distichum)}

Baldcypress (Taxodium distichum (L.) Rich.) are deciduousneedled pyramidal trees that can reach 100 to 150 feet in height. They grow at a moderately fast rate, reaching 40 to 50 feet in the first 15 to 25 years. They are commonly found throughout the state of Florida, particularly near lakes and rivers (as they are native to wetlands along running streams), and can also be found throughout most of the eastern United States in USDA hardiness zones 5A through 10B. Growth is fastest on moist, well-drained soils in full sun. Trees are highly tolerant of drought, although they are adapted to thrive in wetlands, where they will develop "knees," a distinct structure that forms above the roots. They will also grow well in upland sites with few to no "knees" (Gilman and Watson 2014).

\section{Key Pests: Baldcypress}

This series of Key Plant, Key Pests publications is designed for Florida gardeners, horticulturalists, and landscape professionals to help identify common pests associated with common Florida flora. This publication, the first in the Key Plant, Key Pests series, helps identify the most common pests found on the Baldcypress (Taxodium distichum).

This publication provides information and general management recommendations for the cypress leaf beetle, fall webworm, cypress twig gall midge, mealybugs, rust mites, and needle blights. For a more comprehensive guide of woody ornamental insect management, download the current Professional Disease Management Guide for Ornamental Plants here or the Integrated Pest Management in the Commercial Ornamental Nursery Guide here.

\section{Cypress Leaf Beetle: Systena marginalis}

Recognition: Foliage will appear discolored, turning into a bright to dark red with small, linear gouges (approx. $1 / 10$-inch long) in the needles. Adult beetles are small (approx. 1/5-inch long) with a pale-yellow head and body and black markings on the outer margins of the body. They congregate in large numbers in tree crowns and feed on needles. Larvae feed on roots of grasses and weeds.

1. This document is ENH1293, one of a series of the Environmental Horticulture Department, UF/IFAS Extension. Original publication date June 2018. Visit the EDIS website at http://edis.ifas.ufl.edu.

2. Juanita Popenoe, multi-county commercial fruit production agent IV; Caroline Roper Warwick, science communication specialist; and Roger Kjelgren, center director; Mid-Florida Research and Education Center, UF/IFAS Extension, Apopka, FL 32703.

The Institute of Food and Agricultural Sciences (IFAS) is an Equal Opportunity Institution authorized to provide research, educational information and other services

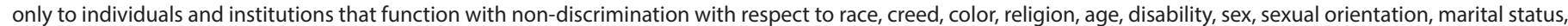

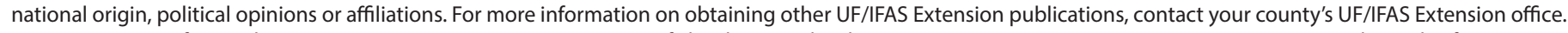
U.S. Department of Agriculture, UF/IFAS Extension Service, University of Florida, IFAS, Florida A \& M University Cooperative Extension Program, and Boards of County Commissioners Cooperating. Nick T. Place, dean for UF/IFAS Extension. 
Contributing Factors: Adults are active in June and July. Drought or other stress factors can bring on similar needle color change, so it is important to properly scout and identify beetles.

Management Recommendations: In the nursery, direct sprays at adults when they are found or apply larvicide to soil in grass and weeds around the nursery. In landscape trees, trees will usually refoliate in the same growing season and no control is needed (Jacques 1987).

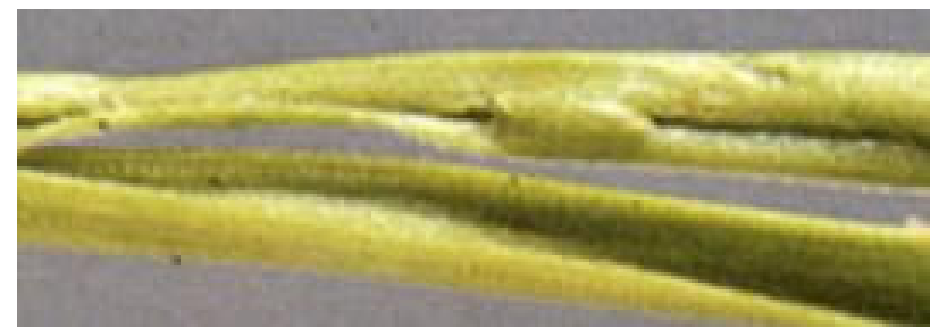

Figure 2. Leaves damaged by adult cypress leaf beetles. Credits: Florida Department of Agriculture and Consumer Services.

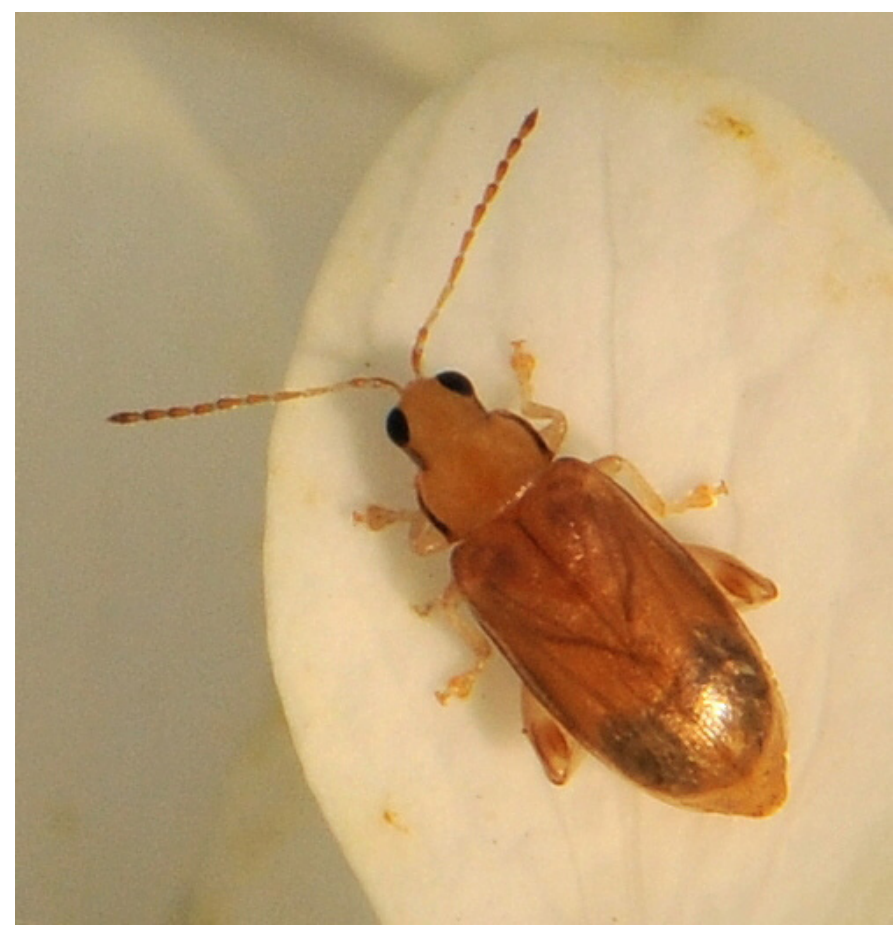

Figure 3. The cypress leaf beetle.

Credits: Ted Kropiewnicki, bugguide.net

\section{Fall Webworm: Hyphantria cunea}

Recognition: Larvae of the black-headed strain are pale yellow or greenish with two rows of black spots along the back, scattered long hairs, and black head capsules. After feeding, the caterpillars hide in bark crevices and other protected areas on the ground and change into amberbrown pupa inside a loose cocoon. The adult is a white moth that deposits about 200 to 300 eggs in one mass on the underside of leaves. Moths are attracted to light during the night. Starting in the spring, this caterpillar has several generations per year, with the later occurring generations becoming more noticeable and extensive webbing in late September.

Contributing Factors: The primary contributing factors for webworms are unknown, as their presence is sporadic.

Management Recommendations: Use controls specific for caterpillars. Adequate spray penetration is difficult through webbing (Sourakov and Paris 2010).

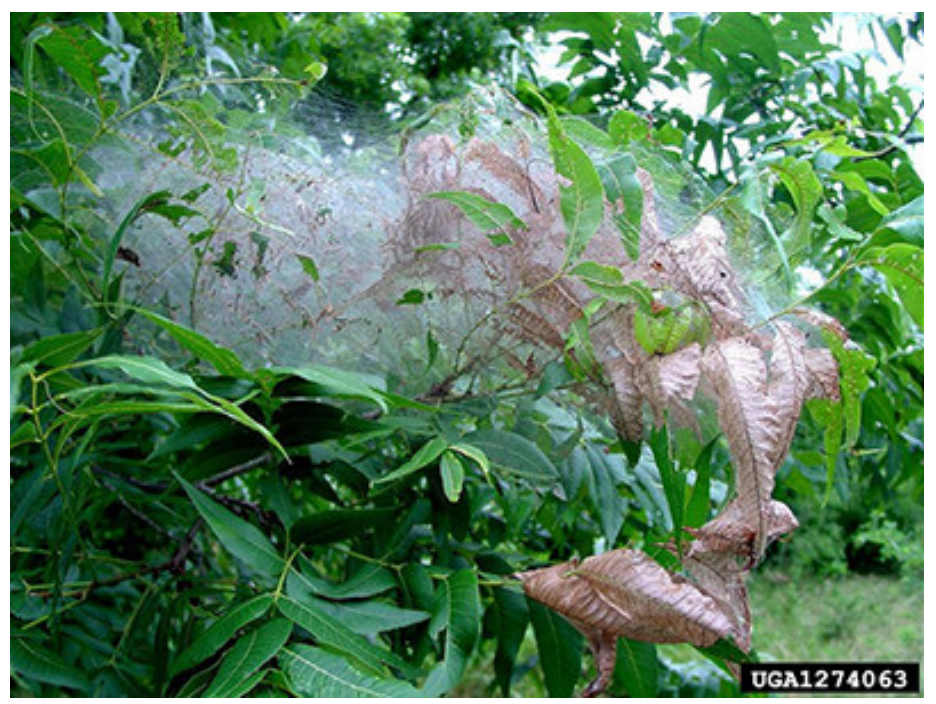

Figure 4. Fall webworm damage.

Credits: Ronald F. Billings, Texas Forest Service, bugwood.org

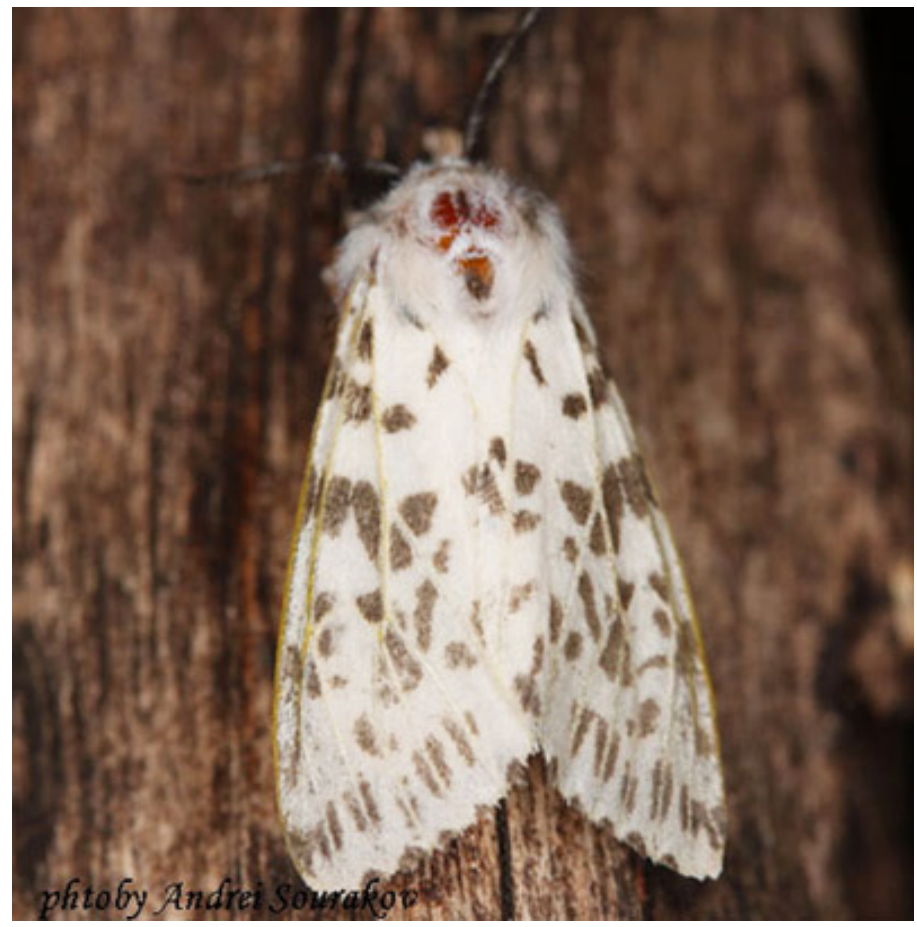

Figure 5. An adult fall webworm.

Credits: Andrei Sourakov, Florida Museum of Natural History, University of Florida 


\section{Cypress Twig Gall Midge: Taxodiomyia cupressiananassa}

Recognition: Heavy, spongy galls of varying sizes are created when female flies lay their eggs on newly developing leaves. The oval, green galls are heavy enough to cause branches to droop under their weight if there are too many on the branch. Each gall may contain up to 15 yelloworange maggots in individual cells. In the autumn, the galls turn brown and drop to the ground with the leaves, and the larvae over-winter in the gall. The adults emerge as flies and can be found for about a month beginning in mid-May. There are two generations per year.

Contributing Factors: The main contributing factor of cypress twig gall midges is previous infestations of this insect.

Management Recommendations: To reduce the number of galls in a new season, rake and destroy the fallen leaves and galls. Sprays can be directed at adults when they are scouted, but there are many natural enemies and biological controls of this insect (Gomez and Mizell 2013).

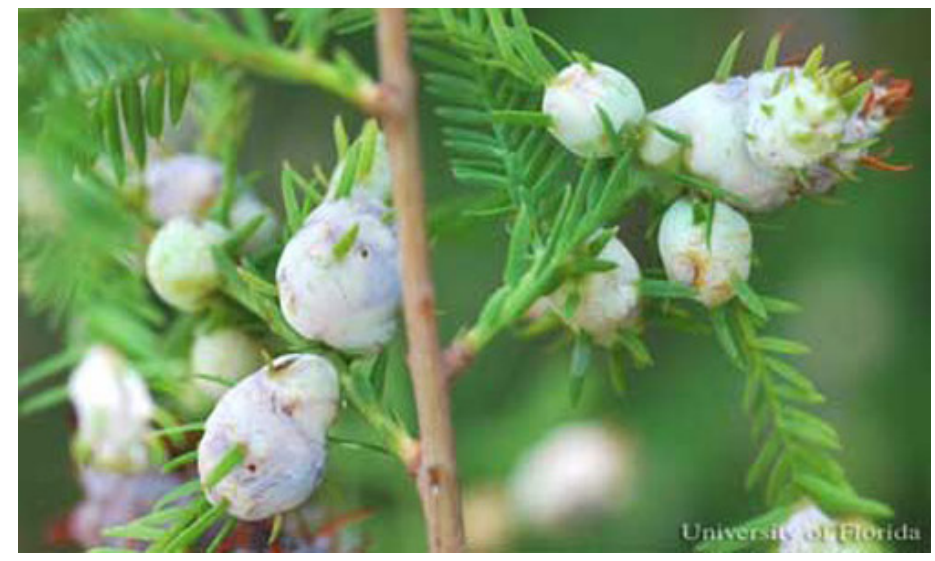

Figure 6 . The cypress twig gall midge leaves round galls on tree branches, as pictured here.

Credits: Russel F. Mizell III, UF/IFAS

\section{Mealybugs}

Recognition: Mealybugs are soft-bodied insects with piercing-sucking mouthparts and a wooly, white, waxy covering. A byproduct of mealybug feeding is sticky honeydew, which coats infested foliage and provides a medium for growth of black sooty mold fungi. Mealybug reproduction is increased in humid and hot environments.

Contributing Factors: Contributing factors for mealybugs, specifically for Baldcypress, is unknown.

Management Recommendations: Predators (like lady bug larvae) can control many mealybug infestations in the landscape. The waxy covering protects the insects from sprays. Horticultural oils or systemic insecticides can be effective in controlling mealybugs, but because Baldcypress is very sensitive to horticultural oils, extreme caution should be used when making the decision to apply (UF/ IFAS 2015).

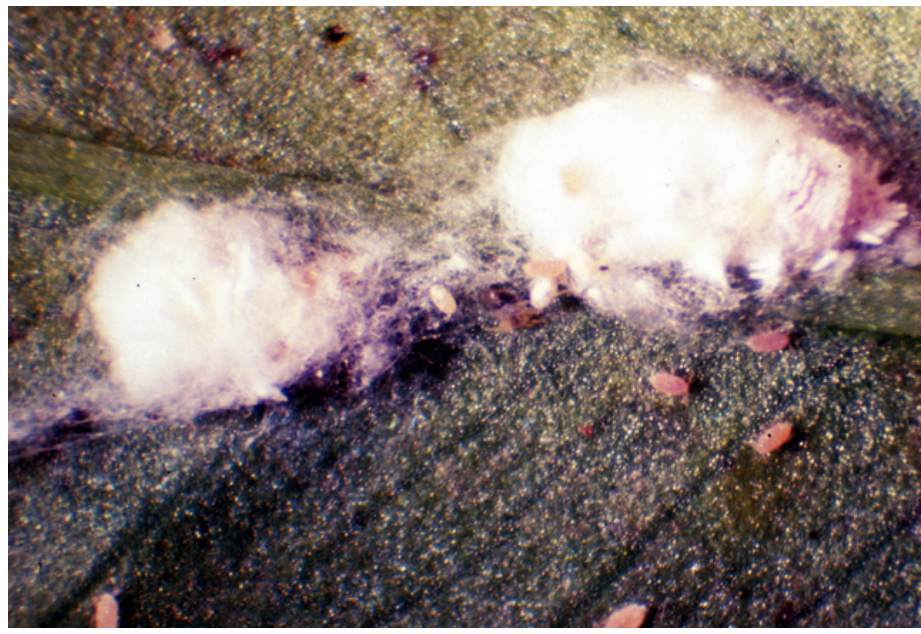

Figure 7. Mealybug egg sacs can contain up to 300 eggs. Credits: Lance Osborne, UF/IFAS

\section{Rust Mites}

Recognition: The Baldcypress Rust Mite is a microscopic eriophyid mite, most active during the warm season, which causes browning of interior needles. It overwinters in bark crevices, ready to reproduce and infest new growth in the spring. The mites' mouthparts rasp the leaf cells, causing the needles to become yellowish and then brown. Mites can be seen with a 10-power hand lens, and their white cast skins are the best diagnostic.

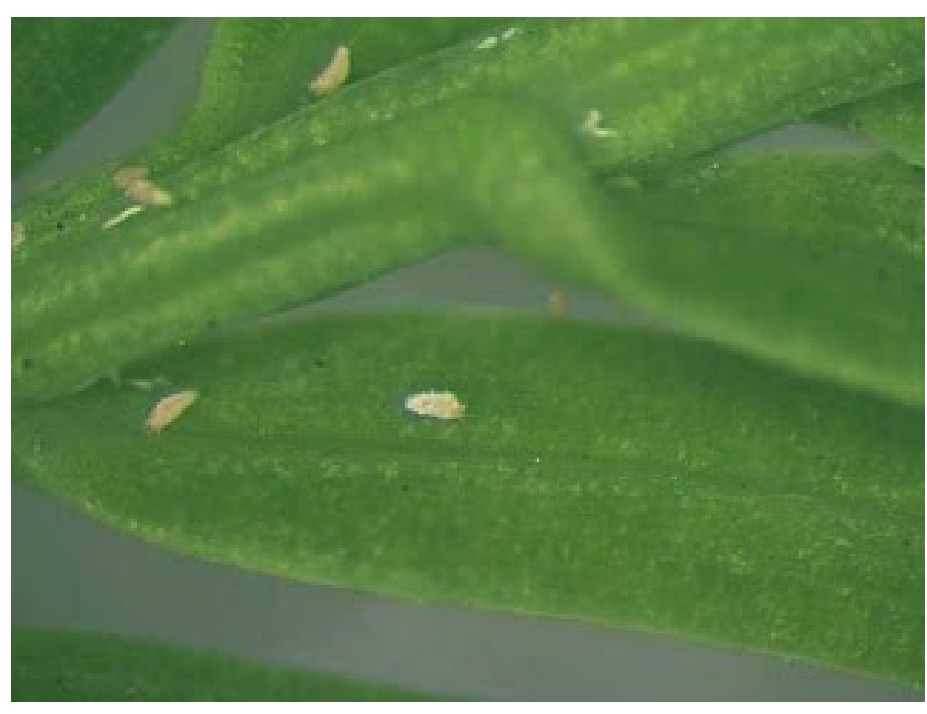

Figure 8. Bald Cypress Rust Mites.

Credits: Dr. Casey Sclar, Longwood Gardens Image Archives 
Contributing Factors: Warm weather causes very rapid reproduction.

Management Recommendations: Carbaryl, dicofol, and oxythioquinox will knock down this mite with thorough foliage coverage (Nixon and Sheltar 1998). Please consult the most up-to-date regulations before applying any pesticides.

\section{Needle Blights: Asperisporium, Pestalotia, Phomas spp.}

Recognition: Needle blights are fungal diseases that are capable of causing new infections on trees throughout the growing season. The fungus reproduces inside lesions on the tree and spreads rapidly, through wind, animal, or human interaction. Needle blight infestations cause spotting of the needles, cones, and bark. In very wet seasons, this may become a twig blight.

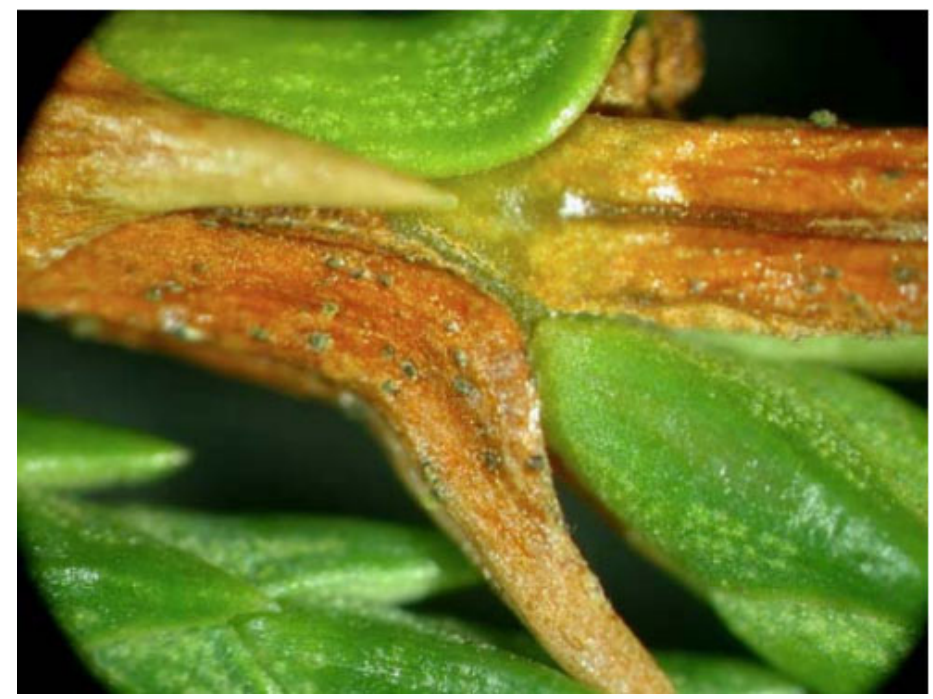

Figure 9. Tuft-like spore-producing fruiting bodies of needle blight. Credits: Dr. Dennis Hazel, North Carolina State University

Contributing Factors: Trees weakened by dry weather, sunscald, or low temperatures.

Management Recommendations: Keep plants from becoming stressed. Prune and remove affected plant tissue. Fungicide recommendations can be found on the Professional Disease Management Guide for Ornamental Plants (PP-202) (Warfield and Hazel n.d.).

\section{References}

Gilman, E. F. and D. G. Watson. 1994. "Taxodium distichum: Baldcypress." http://edis.ifas.ufl.edu/pdffiles/ST/ ST62000.pdf
Gomez, C. and R. F. Mizell, III. 2013. "Cypress twig gall midge, Taxodiomyia cupressiananassa Osten Sacken.” http:// entnemdept.ufl.edu/creatures/orn/trees/cypress_twig_gall_ midge.htm

University of Florida Institute of Food and Agricultural Sciences. 2015. "Mealybugs." http://mrec.ifas.ufl.edu/lso/ entomol/ncstate/mealy.htm

Jacques, R. L. 1987. "Flea beetles of the genus Systena in Florida. Florida Department of Agriculture and Consumer Services, Division of Plant Industry." http://www.freshfromflorida.com/content/download/10687/140413/ent295.pdf

Nixon, P. and D. Sheltar. 1998. "Bald cypress rust mite. Home, Yard and Garden Pest Newsletter, College of Agricultural, Consumer and Environmental Sciences, University of Illinois at Urbana-Champaign." http://hyg.ipm.illinois. edu/pastpest/199815g.html

Souravok, A. and T. Paris. 2014. "Fall webworm, Hyphantria cunea Drury." http://entnemdept.ufl.edu/creatures/trees/ moths/fall_webworm.htm 